\title{
Investigating the impact of viral message appeal and message credibility on consumer attitude toward the brand
}

\author{
Majid ESMAEILPOUR \\ Persian Gulf University, Bushehr, Iran \\ majidesmailpour@yaho.com \\ Farshad ARAM \\ Persian Gulf University, Bushehr, Iran
}

\begin{abstract}
Due to the rapid growth of the Internet and use of e-commerce in the recent years, viral marketing has drawn the attention of manufacturing and service organizations. However, no research has been conducted to examine the impact of message appeal and message source credibility on consumers' attitude with mediating role of intellectual involvement of consumers and their risk taking level. The aim of this study was to examine the impact of appeal and message source credibility on consumers' attitude with mediating role of consumers' intellectual involvement and their risk taking level. The population of this study includes consumers of mobile phones (Samsung, Sony, Nokia, LG and iPhone) in the Bushehr city (Iran). As the population of the study is unlimited, 430 questionnaires were distributed using available sampling method, and 391 questionnaires were collected and analyzed. Using structural equation modeling, we analysed the data through smart PLS software. The results show that the appeal and credibility of the message source impact the consumer attitudes toward the brand. We also found that the intellectual involvement of consumers plays the mediating role in the relationship between message appeal and consumer attitudes toward brands. In the relationship between message source credibility and customer attitude towards the brand, the level of risk taking of people has no mediating role.
\end{abstract}

Keywords: viral marketing, message appeal, message source credibility, consumer attitude, the level of intellectual involvement, the level of risk taking.

Please cite the article as follows: Esmaeilpour, M. and Aram, F. (2016), "Investigating the impact of viral message appeal and message credibility on consumer attitude toward the brand", Management \& Marketing. Challenges for the Knowledge Society, Vol. 11, No. 2, pp. 470-483. DOI: 10.1515/mmcks-2016-0010.

\section{Introduction}

Nowadays, most people, especially young people, use the Internet or tend to use social networks. The newly created space has provided some threats and opportunities for companies. It has also caused marketers to revise their marketing methods and pay more attention to the impact of the Internet network on marketing methods. On the other hand, the word of mouth marketing refers to the transmission of information among users through language (Wu and Wang, 2011).

Viral Marketing is generally a combination of word of mouth marketing and Internet networks. It means that consumers send brand messages of the company over the Internet network to each other. Two very important features of this type of marketing are high speed and low cost (Kaplan and Haenlein, 2011). In viral marketing, the message must be designed in a way that it can attract people and persuade them to send this message to their family and friends. These messages are sent by users to each 
other via the Internet (Bahrainizadeh and Zamani, 2011). Experts believe that many factors affect the success and effectiveness of viral marketing that these factors either relate to those consumers who are exposed to the message or relate to the message properties or situation, and the context in which the message is sent (Kaplan and Haenlein, 2011). Yang et al. (2012) indicated that when customers see themselves at the risk of buying, they seek the credible information and this information includes information sent through word of mouth or through other credible sources. If the receiver of the message believes that the message source is credible, the impact of this message on people's attitude toward the product and brand will be more than when a person feels that the message has lower credibility (Cheung et al., 2008).

McKinney (2002) also states that based on the satisfaction of the Web model, understandability, reliability, and usefulness of the information are three basic dimensions of quality information in viral marketing affecting consumer attitude toward the brand (Cheung et al., 2008). Based on what has been said, companies might be aware of the type of relationship between message appeal and consumers' attitude in light of these studies. Unfortunately, a very limited number of studies has been conducted on viral marketing and on the investigation of variables that can be used while implementing viral marketing. Therefore, due to the increasing importance of viral marketing and the word of mouth marketing in the advertising strategies and methods of the companies, this study was conducted to examine the impact of emotional appeal and credibility of the message on consumers' attitude toward the brand.

\section{Literature review and background of study \\ Word of mouth marketing and viral marketing}

What lead to stories like Harry Potter to be popular and famous among young people? It can be said that the word of mouth marketing has played the main role in the popularity of these stories. Word of mouth marketing means that customers will transmit positive or negative experiences of a given product or anything else that they like to others and, in this manner, people become an advertising factor for a product (Proctor and Richard, 2002). Word of mouth marketing is a type of informal communication on evaluation of products and services among customers. In this type of marketing, customers themselves play the role of marketers for the company. Word of mouth marketing plays an important role in shaping the attitudes and behavior of consumers (Lim and Chung, 2014). A vital component in the marketing process for any organization is the use word of mouth marketing because consumers become an advertiser for the organization in this type of marketing (Dinh and Mai, 2016). Viral marketing means disseminating a message or content that contains advertising or information about a company's brand through social media. In other words, it can be stated that viral marketing is a strategy encouraging people to send the advertising messages to each other. In this type of marketing, the advertising message is disseminated as a virus among people (Beverland et al., 2014). For the better implementation of viral marketing, two variables like message appeal and message source credibility can play an important role (Wu and Wang, 2011).

Message appeal: $\mathrm{Wu}$ and Wang (2011) suggest that message appeal emotionally or intellectually affects consumer attitudes towards a product and brand. Emotional appeal affects a person emotionally, and intellectual appeal represents a benefit that consumers find from product. In other words, the intellectual appeal is the focus of message on product features that have benefit for the consumer. The emotional appeal of the message means to stimulate consumer through his emotion or feeling (Noble and

Vol. 11, No. 2, Spring, pp. 470-484, ISSN 1842-0206 | Management \& Marketing. Challenges for the Knowledge Society 
MMCKS Johnson, 2013). Emotions and social sharing of the emotions phenomenon is a key element in viral communications. Dobele et al. (2007) state that advertising the message 472 of the company should establish an emotional communication between the company or brand, and the message receiver so that the company to be sure that the consumers will send this message to others and it will affect them.

Message source credibility: The message source credibility means how much the receiver of the message trusts the sender and it reflects the mindset of the receiver of the message to sender. It represents consumers' attitude in relation to the source of the message (Gunther, 1992). From the perspective of Wu and Wang (2011), a credible message has two basic components including reliability and expertise. Reliability reflects the amount of trust and acceptance that the receiver of the message has toward the sender that includes being reliable, unreliability, being honest- not being honest, being reliable, not being reliable, being sincere, and insincerity. Expertise represents having the knowledge that the sender of a message has about the product which includes specialized message, lack of specialized message, being experimental, not being experimental, being knowledgeable, not being knowledgeable, being qualified, not being qualified (Wu and Wang , 2011).

\section{Consumer attitude towards the brand}

According to the American Marketing Association, the brand is a name, term, symbol, design or a combination of these items, reflecting the main nature of a company or a service (Vazifehdust et al., 2010). The rand is something more than a mere name, since it contains all communications that the customer establishes with the features of the products (Maleki et al., 2015). According to Keller (1998), the brand has three components that include brand attitude, brand benefits, and brand reputation. According to him, brand attitude is the belief of the people to benefit from the reputation, performance, and experience of the brand. A strong belief in environmental performance of brand leads to a positive attitude towards the brand. Attitude includes favorable and unfavorable evaluations, emotions or feelings and behavioral attitudes (Wu and Wang, 2011).

According to Wu and Wang (2011), the attitude consists of three components: the cognitive component includes knowledge and understanding that consumers obtain after consuming the product or receiving the information; the stimulating component is the emotional reactions of consumers toward the brand representing consumer evaluation of the product or brand; effort component: it represents hatred, tendency, behavior, or individual performances toward a product or brand.

On the other hand, according to Kachersky et al. (2015), people attitude toward the brand can include three components: cognitive, emotional and functional.

\section{Level of intellectual involvement}

There are different definitions of intellectual involvement. The key component of this concept is personal dependence or attachment and there is a general agreement that the level of intellectual involvement of consumer to a target is determined based on its importance to the consumer (O'Reilly and Marx, 2011). The level of intellectual involvement reflects the importance of that product to the customer and represents the consumer interest in the product (Yang et al., 2012). Intellectual involvement is defined as perceived dependence or attachment of a target based on basic needs, values, and interests. The word target is used in a general sense and refers to a product or brand, advertising or a shopping situation (Nowrouzi and Qalandari, 2009). 


\section{Level of risk taking}

Consumers differ in terms of risk taking. Studies show that the level of risk taking of people depends on the internal factors of the person and it does not depend on the external considerations of the market. Risk includes two components of the uncertainty of the results and the importance of negative results of a choice, and people may differ in both components and they may differ from one situation to another (Vazifehdust et al., 2010). Gounaris and Stathakopoulos (2010) believe that consumers become loyal to one product or brand to reduce the perceived risk. This loyalty is high in risk-averse people. They showed that consumers' risk-averseness leads to loyalty and their dependence on one brand (Bahrainizadeh and Ziaei, 2012).

\section{The relationship between message appeal, message credibility and consumer attitude toward brand}

Using appeal in advertising message is known strategy in advertising, since merely information in a message does not lead to the motivation of consumers but stimulating the feelings leads to motivation (Wang and Lee, 2005). Hawkins et al. (2003) state that rational appeal acts through rational reasoning and leads to change in behavior and belief of consumer toward brand through thinking. In contrast, emotional appeal stimulates the person psychologically leading to change in attitude and behavior of the person. Additionally, Kim and Lee (2012) suggest that message appeal affects sender expertise and message source credibility, that is one component of message source credibility, affects the consumer attitude toward brand indirectly. Generally, customers mostly like to receive information sent to them through non-profit organizations. If the message is sent from a non-profit organization, people will pay more attention compared to the message sent from a business or manufacturing company (Smith et al., 2005). Recent research also showed that source message credibility has a significant impact on consumer attitudes and plays an important role in the effectiveness of advertising companies. Source of message credibility means creditability of message sender (Clow et al., 2006). Credibility of source of message sent via internet affects the perception of consumer to information sent for him and it leads to creation of positive attitude in consumer toward product brand at the same time (Chiou and Hsu). Kim and Lee (2012) suggest that message appeal affects sender expertise and message source credibility, that is one component of message source credibility, affects indirectly the consumer attitude toward brand.

According to the literature mentioned, the following hypotheses are proposed:

$\boldsymbol{H}_{1}$ : The appeal of viral message can have a positive impact on the consumer attitude toward the brand.

$\boldsymbol{H}_{2}$ : Message source credibility has a positive impact on the consumer attitude toward the brand.

\section{The mediating role of the level of intellectual involvement and risk taking}

In a study conducted by $\mathrm{Wu}$ and Wang (2011), the level of intellectual involvement of consumers in product selection was considereda mediating variable that affects message credibility and consumer attitude. Personal attitudes are divided based on whether the person accepts or rejects a subject. Therefore, the individual involvement level is the most important factor influencing people's attitudes (Wang and Li, 2005). O'Reilly and Marx (2011) suggest that the people's risk taking level mediates the relationship between message source credibility and people attitude toward the brand. Whenever people have lower levels of risk taking, they will be more careful and pay more attention 
to message source credibility. On other hand, when the advertising message has a more credible source from one's perspective, it will lead to positive attitude in the person toward the product or the company. According to literature mentioned, the following hypotheses are proposed:

$\boldsymbol{H}_{3}$ : In the relationship between a message source credibility and consumer attitude toward the brand, the level of consumer risk taking plays the mediating role.

$\boldsymbol{H}_{4}$ : In the relationship between message appeal and consumer attitude toward the brand, the level of consumer involvement plays the mediating role.

Table 1, shows the summary of studies conducted on research variables and their relationship.

Table 1. Research literature

\begin{tabular}{|c|c|c|c|}
\hline No. & Title of research & $\begin{array}{l}\text { Researcher/ } \\
\text { researchers }\end{array}$ & Results of findings \\
\hline 1 & $\begin{array}{l}\text { Investigating the } \\
\text { effects of } \\
\text { electronic word of } \\
\text { mouth marketing }\end{array}$ & $\begin{array}{l}\text { Cheung et al. } \\
\text { (2008) }\end{array}$ & $\begin{array}{l}\text { The results show that two main variables have a significant } \\
\text { impact on the acceptance of information in the word of } \\
\text { mouth marketing. These two variables include logical } \\
\text { quality of the message and source of the message } \\
\text { credibility. In this study, it was shown that two dimensions } \\
\text { of source of message credibility namely expertise and } \\
\text { reliability have direct impact in acceptance of information. }\end{array}$ \\
\hline 2 & $\begin{array}{l}\text { Why viral message } \\
\text { is sent? }\end{array}$ & $\begin{array}{l}\text { Dobele et al. } \\
\quad(2007)\end{array}$ & $\begin{array}{l}\text { In this study, they examined the role of emotions and } \\
\text { feelings in viral messages. The results showed that the } \\
\text { feelings of surprise, cheerfulness and sadness had the } \\
\text { greatest impact on message transmission. }\end{array}$ \\
\hline 3 & $\begin{array}{l}\text { Investigating the } \\
\text { impact of message } \\
\text { credibility and } \\
\text { message appeal on } \\
\text { attitude toward } \\
\text { brand }\end{array}$ & $\begin{array}{l}\text { Wu and Wang } \\
\text { (2011) }\end{array}$ & $\begin{array}{l}\text { The results indicate that the source of message credibility } \\
\text { has direct impact on consumer attitudes toward the brand } \\
\text { in viral marketing. In addition, at the high involvement, } \\
\text { intellectual appeal of the message has high impact on } \\
\text { consumer attitude toward brand. Generally, it can be said } \\
\text { that the source of message credibility has more impact on } \\
\text { consumer attitude compared to message appeal. }\end{array}$ \\
\hline 4 & $\begin{array}{l}\text { How customers } \\
\text { evaluate the } \\
\text { credibility of viral } \\
\text { message? }\end{array}$ & $\begin{array}{l}\text { O'Reilly and } \\
\text { Marx (2011) }\end{array}$ & $\begin{array}{l}\text { The results showed that the level of risk taking and } \\
\text { intellectual involvement of consumers play the mediating } \\
\text { role in relation with consumer attitudes towards brand. } \\
\text { Another finding of this study shows that source of message } \\
\text { credibility depends on four factors of message repetition, } \\
\text { being rational, finding the dependent source, and previous } \\
\text { experience of the brand. }\end{array}$ \\
\hline 5 & $\begin{array}{l}\text { The impact of viral } \\
\text { marketing on } \\
\text { brand }\end{array}$ & Moore (2003) & $\begin{array}{l}\text { This research examines the impact of viral marketing on } \\
\text { the organizations brand and different products. Its results } \\
\text { indicate that viral marketing affects consumers' attitude } \\
\text { toward the brand. }\end{array}$ \\
\hline 6 & $\begin{array}{l}\text { The impact of viral } \\
\text { messages on rate } \\
\text { of message } \\
\text { sending in the } \\
\text { media } \\
\text { communications } \\
\text { process }\end{array}$ & $\begin{array}{l}\text { Jafariani and } \\
\text { Doaee }(2010)\end{array}$ & $\begin{array}{l}\text { The results show that among the various feelings, the } \\
\text { feeling of surprise, cheerfulness and fear have a positive } \\
\text { effect on the rate of transmission of viral message and } \\
\text { sadness virus affects the transmission of viral message } \\
\text { negatively. Additionally, anger and hatred have no effect on } \\
\text { viral message transmission. }\end{array}$ \\
\hline 7 & $\begin{array}{l}\text { Investigating the } \\
\text { impact of word of } \\
\text { mouth marketing } \\
\text { incentives on } \\
\text { consumer attitude }\end{array}$ & $\begin{array}{l}\text { Pongjit and } \\
\text { Beise-Zee } \\
\text { (2015) }\end{array}$ & $\begin{array}{l}\text { The results of this study show that organizations using } \\
\text { word of mouth marketing require long-term incentives. } \\
\text { Additionally, these organizations should use mutual } \\
\text { communications to influence consumers. }\end{array}$ \\
\hline 8 & $\begin{array}{l}\text { Investigating the } \\
\text { impact of TV }\end{array}$ & $\begin{array}{c}\text { Feiz, } \\
\text { Fakharyan, }\end{array}$ & $\begin{array}{l}\text { The results showed that advertising appeal dimensions } \\
\text { (feelings of fear appeal, relative appeal, and humor appeal) }\end{array}$ \\
\hline
\end{tabular}

Vol. 11, No. 2, Spring, pp. 470-484, ISSN 1842-0206| Management \& Marketing. Challenges for the Knowledge Society 


\begin{tabular}{|c|c|c|l|}
\hline $\begin{array}{c}\text { advertising appeal } \\
\text { on consumer } \\
\text { attitude toward } \\
\text { brand }\end{array}$ & $\begin{array}{c}\text { Jalilvand, and } \\
\text { Hashemi } \\
(2013)\end{array}$ & $\begin{array}{l}\text { have impact on consumer attitude toward advertising of a } \\
\text { company. }\end{array}$ \\
\hline
\end{tabular}

Source: Authors' own processing.

\section{Conceptual model of the research}

This study aims to examine the effect of appeal and credibility of the source of viral messages on consumers' attitude toward the brand according to mediating role of the level of intellectual involvement and risk taking level of consumer. By studying the theoretical and experimental literature on the research topic and taking into account the results of the research conducted by Wu and Wang (2011), Wang et al. (2005), O'Reilly and Marx (2011) and Gerard and Liu (2009), we developed the research hypotheses. By identifying the key variables of study and designing the relationships between them through theoretical and experimental literature, the conceptual framework of this study was developed. The conceptual framework of this research is shown in Figure 1.

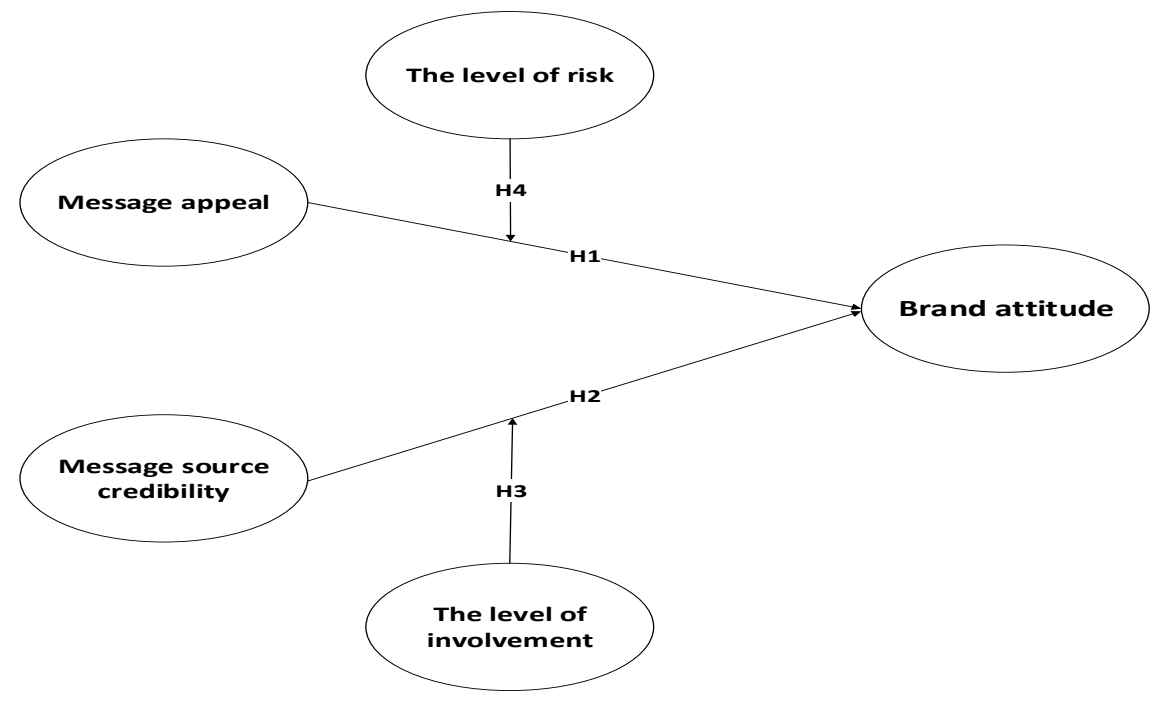

Figure 1. Research Conceptual Model

Source: Authors' own processing

\section{Methodology}

This research is applied in terms of goal, and in terms method of data collection is a descriptive survey and correlation. The study population included all people using mobile phones (Samsung, Sony, Nokia, LG and iPhone) in the city of Bushehr. Due to large population, sampling was used in this study. Based on unlimited population of Cochrane formula, the sample of study was determined to be over 384 subjects at 95 percent confidence level and 5 percent sampling error. In this study, 430 questionnaires were distributed among the population using available sampling that eventually 391 questionnaires were returned. Data was collected through a questionnaire. The questionnaire consists of three parts, including introduction, the demographic questions, and questions measuring the main variables of the research. To measure the research main variables, 28 questions were developed through combining two questionnaires of $\mathrm{Wu}$ and Wang (2011) and O'Reilly and Marx (2011). The five-item Likert scale (from strongly agree to strongly disagree) was used to measure the variables of the study. Table 2 provides information on the development of questions of 
the questionnaire. As the questionnaire of this research was developed by combining two questionnaires of other researchers and validity of variables has already been measured, it can be said that the research questionnaire is valid. However, content validity method was used to determine the validity of the research. For this purpose, the developed questionnaire was provided for a number of university professors in the field of management and marketing and consumers of mobile phones, and they were asked to express their ideas and views on validity of questionnaire. After collecting the views, the final questionnaire was developed. To measure the reliability of the research questionnaire, Cronbach's alpha coefficient was used. Cronbach's alpha coefficient for all variables is higher than 0.7 and it is $83 \%$ for the entire questionnaire, suggesting that reliability of the questionnaire is at the desired level. Additionally, the Average Variance Extracted (AVE) Index was used to measure the validity of the questions of the questionnaire, and composite reliability (CR) coefficient was used to measure the reliability of the questionnaire. Table 2 , shows the results of validity and reliability indices of the questionnaire.

Table 2. Variables of the study and sources to extract the items and the reliability results of data collection tool (questionnaire)

\begin{tabular}{|c|c|c|c|c|c|}
\hline Variable & $\begin{array}{c}\text { Number of } \\
\text { items } \\
\text { (questions) }\end{array}$ & $\begin{array}{c}\text { Resources of } \\
\text { questionnaire }\end{array}$ & AVE & CR & $\begin{array}{c}\text { Cronbach's } \\
\text { alpha } \\
\text { coefficient }\end{array}$ \\
\hline Message appeal & 6 & (Wu and Wang, 2011) & 0.51 & 0.84 & 0.77 \\
\hline $\begin{array}{c}\text { The message source } \\
\text { credibility }\end{array}$ & 6 & $\begin{array}{c}\text { (Wu and Wang, 2011); } \\
\text { (O'Reilly and Marx, } \\
\text { 2011) }\end{array}$ & 0.62 & 0.92 & 0.71 \\
\hline $\begin{array}{c}\text { Consumer attitude } \\
\text { toward brand }\end{array}$ & 8 & (Wu and Wang, 2011) & 0.61 & 0.85 & 0.80 \\
\hline $\begin{array}{c}\text { Level of consumer } \\
\text { involvement }\end{array}$ & 4 & (Wu and Wang, 2011) & 0.63 & 0.66 & 0.77 \\
\hline Level of consumer risk & 4 & (O'Reilly and Marx, & 0.65 & 0.84 & 0.73 \\
\hline Total questionnaire & 28 & & & & 0.83 \\
\hline
\end{tabular}

Source: Authors' own processing

In order to calculate the convergent validity, the AVE index was used. If the AVE value is at least equal to 0.5 , it indicates that the variables have good convergent validity. This means that latent variable can explain more than half of the variance of the visible or observed variable on average. As average variance extracted (AVE) index for all variables was higher than 0.5 in this study, convergent validity of model variables was confirmed. Composite reliability (CR) coefficient and Cronbach's alpha coefficient measure the reliability of the questionnaire. As Table 2 shows, since composite reliability coefficient (CR) and alpha coefficient are higher than 0.7 for all variables of study, the reliability of the questions in the questionnaire is at acceptable range.To test the hypotheses and conceptual model of study, structural equation modeling (Partial Least Squares) through smart PLS software was used.

\section{Data analyses and results Descriptive results of the research data}


To analyze the data, descriptive statistics was used to analyze demographic variables. MMCKS Table 3 , is related to demographic variables of the study that they were analyzed through collecting 391 questionnaires.

Table 3. Demographic characteristics of respondents

\begin{tabular}{|c|c|c|}
\hline Demographic variable & Levels & $\begin{array}{c}\text { Percentage } \\
\text { of } \\
\text { frequency }\end{array}$ \\
\hline \multirow{2}{*}{ Gender } & Male & 53.8 \\
& Female & 41.7 \\
\hline \multirow{3}{*}{ Education } & Diploma and lower & 15 \\
& Associate & 20 \\
& Undergraduate & 45 \\
& Graduate and higher & 20 \\
\hline \multirow{2}{*}{ Age } & 18 to 25 years & 24.8 \\
& 26 to 35 years & 38.4 \\
& 36 to 45 years & 27.3 \\
& Over 45 years & 9.5 \\
\hline \multirow{2}{*}{ Phone brand } & Sony & 27.3 \\
& Nokia & 35 \\
& Samsung & 20.2 \\
& LG & 6.8 \\
& iPhone & 5.8 \\
\hline
\end{tabular}

Source: Authors' own processing.

As shown in Table 3, 53\% of respondents are men and $41 \%$ of them are female. In addition, $27 \%$ of them are consumers of Sony, $35 \%$ of them are consumers of Nokia, $20 \%$ of them are consumers of Samsung, $7 \%$ of them are consumers of LG and only $6 \%$ of them are consumers of iPhone. Moreover, 15\% of respondents have diploma and lower, $20 \%$ of them have an associate's degree, $45 \%$ of them are undergraduate, and $20 \%$ of them are graduate and higher.

The data in Table 4 show that the highest mean was related to level of risk taking and the lowest mean was related to people involvement level with product. Additionally, the highest standard of deviation was related to consumer attitude and the lowest standard of deviation was related to message appeal.

Table 4. Descriptive information of research variables

\begin{tabular}{|c|c|c|c|c|}
\hline Variable & Mean & SD & Kurtosis & Skewness \\
\hline Message source credibility & 3.41 & 0.85 & -0.894 & -0.139 \\
\hline Message appeal & 3.61 & 0.75 & 0.234 & -0.254 \\
\hline $\begin{array}{c}\text { Consumer attitude } \\
\text { towards brand }\end{array}$ & 3.52 & 0.97 & -0.485 & 0.453 \\
\hline $\begin{array}{c}\text { Level of consumer } \\
\text { involvement }\end{array}$ & 3.40 & 0.77 & -0.651 & 0.582 \\
\hline Level of consumer risk & 3.64 & 0.79 & 0.875 & 0.039 \\
\hline
\end{tabular}

Source: Authors' own processing.

As Table 4 shows, the highest mean was related to level of consumer risk and the highest standard of deviation was related to Consumer attitude towards brand. In addition, the indices of Skewness and Kurtosis show that research data are distributed normally.

\section{Testing the conceptual model of research}

The conceptual model and research hypotheses were tested using structural equation modeling through smart PLS software. All variables of study were converted into visible or observed and latent variables. Observed variables (rectangles) are measured directly by the researcher, while the latent variables (Oval) are not measured directly, but they 
MMCKS are inferred based on relationships or correlations among the measured variables. Latent variables represent some theoretical constructs that are not visible directly, while they are constructed and observed through other observed variables. Figure 2 shows the model of the study in the estimation of the path coefficients mode.

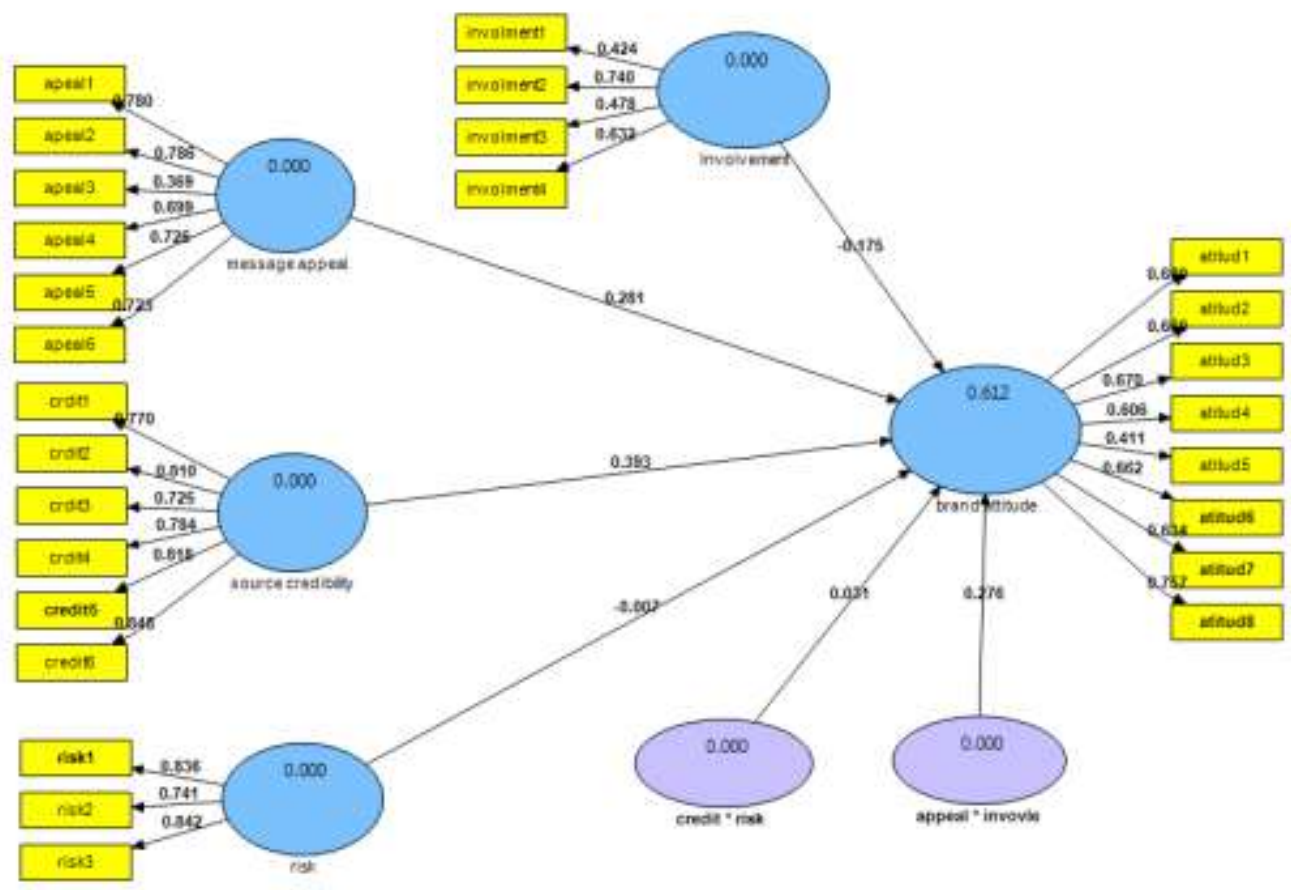

Figure 2. Confirmatory factor analysis, measurement and structural model with along standardized coefficients values

Source: Authors' own processing.

The numbers in the oval are determination index. The coefficient of determination (R2) examines that what percentage of the variance of a dependent variable is explained by independent variable(s). Therefore, it is natural that this value for the independent variable to be zero and more than zero for the dependent variable. When this value is higher, the impact of independent variables on dependent variable will be higher. Therefore, we can say that three variables of message source credibility, message appeal, level of consumer involvement and level of risk taking could explain the consumer attitude variable. The remaining percentage is related to prediction error and it can include other affecting factors that they were not considered in this study.

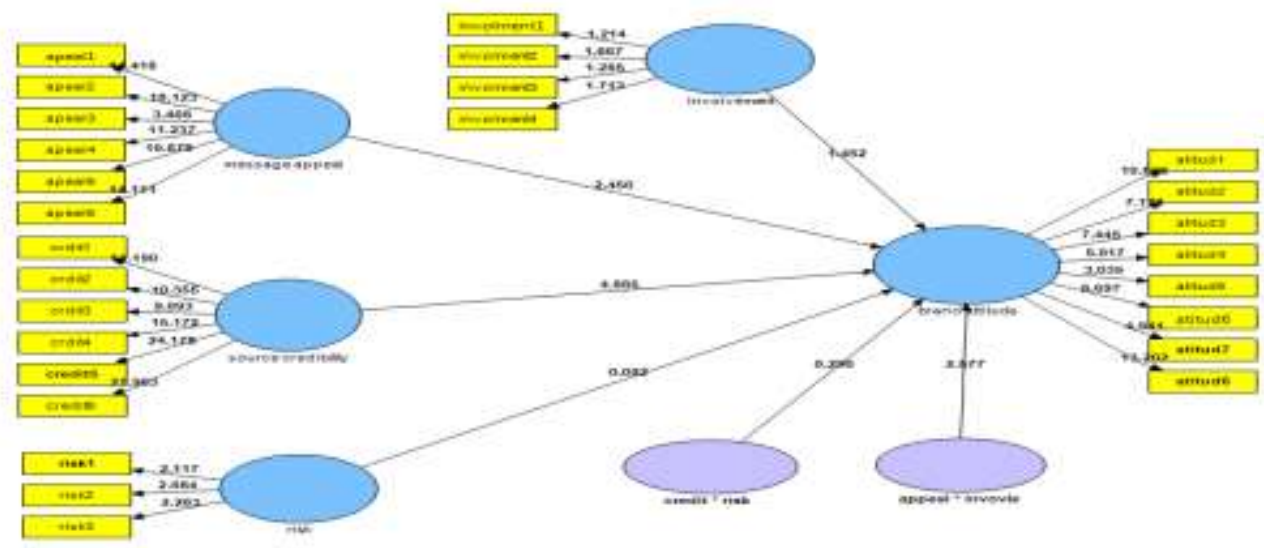

Vol. 11, No. 2, Spring, pp. 470-484, ISSN 1842-0206 | Management \& Marketing. Challenges for the Knowledge Society 

significance coefficients ( $t$-value)

Source: Authors' own processing

Figure 3 shows different model of research in significance coefficients absolute value mode (|t-value|). In fact, this model tests all measurement equations (factorial loads) and structural modeling (path coefficients) using statistic t. According to this model, if the value of statistic $t$ is higher than 1.96, path coefficnet and factorial load will be significant at the $95 \%$ confidence level, and if the value of statistic $t$ is lower than 1.96, factorial load or path coefficinet will not be significant. Additionally, if the value of statistic $t$ is more than 2.58, path coefficient and factorial load will be significant at the confidence level of $99 \%$.

After extracting data related to confirmatory factor analysis, we can test the main hypotheses of research. According to the results obtained from the path coefficients and significance coefficients or statistics t (Figures 2 and 3), we can say that message source credibility has positive and significant impact on consumer attitudes at a confidence level of 99\%. Additionally, message appeal has a significant positive impact on consumer attitude. It was also found that the intellectual involvement of consumers plays mediating role in the relationship between message appeal and consumer attitude toward brand. However, people the level of risk taking does not play the mediating role in the relationship between message source credibility and consumer attitude toward brand. Table 4 shows the summery of testing the main hypotheses of the study.

Table 5. Testing the main hypotheses of the study

\begin{tabular}{|l|c|c|c|c|}
\hline Hypotheses & $\begin{array}{c}\text { Standardized } \\
\text { path } \\
\text { coefficient }\end{array}$ & $\begin{array}{c}\text { t- } \\
\text { value }\end{array}$ & P-value & Result \\
\hline $\begin{array}{l}\mathrm{H}_{1}: \text { The appeal of viral message can have a } \\
\text { positive impact on consumer attitude } \\
\text { toward the brand }\end{array}$ & 0.281 & 2.450 & 0.000 & Accepted \\
\hline $\begin{array}{l}\mathrm{H}_{2}: \text { Message source credibility has a } \\
\text { positive impact on consumer attitude } \\
\text { toward brand. }\end{array}$ & 0.394 & 4.885 & 0.000 & Accepted \\
\hline $\begin{array}{l}\mathrm{H}_{3}: \text { In the relationship between a message } \\
\text { source credibility and consumer attitude } \\
\text { toward the brand, the level of consumer } \\
\text { risk taking plays the mediating role. }\end{array}$ & 0.031 & 0.290 & 0.097 & Rejected \\
\hline $\begin{array}{l}\mathrm{H}_{4}: \text { In the relationship between message } \\
\text { appeal and consumer attitude toward the } \\
\text { brand, the level of consumer involvement } \\
\text { plays the mediating role. }\end{array}$ & 0.276 & 2.577 & 0.000 & Accepted \\
\hline
\end{tabular}

Source: Authors' own processing.

\section{Conclusion and recommendation}

In this study, the effect of message appeal and message source credibility on consumer attitude to brand was examined. The risk taking level of consumer and his involvement level were considered as mediating variables. The results of this study showed that consumer level of involvement, message appeal, and message source credibility are very important factors affecting the attitude of consumer (brand trust, brand interest, and purchasing severity of consumer). The first result indicates that the message source credibility has significant positive impact on consumer attitude toward brand. It means that if consumer realizes that the source of viral message sent for him is credible, he finds a positive attitude to brand or product of the company. In addition, consumers send these messages to others when they recognize that sources of the message are 
credible. Therefore, to increase the effectiveness of the word of mouth marketing, companies should increase their professionalism and message source credibility. Professionalism emphasizes on knowledge and experience of providers. This result is consistent with the results of researchers such as Gerard and Liu (2009), Clow et al. (2006), and Wu and Wang (2011). The second result showed that message appeal has significant and positive impact on consumer attitude toward the brand. This means that how viral messages that companies send them for consumers are appealing from the consumers' perspective. When they find these messages appealing, they will more likely send them for others. Therefore, it is better for companies using viral marketing to use intellectual and emotional appeals.

The results of the research are consistent with results of researchers such as $\mathrm{Wu}$ and Wang (2011), Jafariani and Doaee (2010), and Kim and Lee (2012). In this study, it was hypothesized that the intellectual involvement of consumer has the mediating role in the relationship between message appeal and consumer attitude toward brand. The results of this study showed that this hypothesis is confirmed. The results of this study show that this hypothesis is confirmed at 95\%. By confirming this hypothesis, it can be stated that consumers who have a high level of intellectual involvement, if advertising messages sent to them are appealing (rational and emotional appeal), they will find positive attitude to the considered brand and they will sent the message for others. Therefore, it is better for companies using viral advertising to send advertising messages to people who have a higher level of involvement.

Another result shows that risk-taking level of people has no mediating role in the relationship between message source credibility and consumer attitude toward a brand. However, O'Reilly and Marx (2011) point out that people risk taking level can have mediating role in the relation with consumer attitude. It seems that due to cultural differences or differences in the type of products chosen, the result of the study is not consistent with results of other researchers. The findings of this study indicate that the use of viral marketing and word of mouth marketing requires using credible sources. Based on studies conducted, it was found that in the products that people have lower involvement level, it is better that emotional message to be used so that people send the messages to each other. In general, the results showed that the source of the message credibility has significant and positive impact on consumer attitudes, purchase intention, brand interest and brand honesty. The results of this study also show that message appeal has a positive impact on the attitude. This finding says for companies using viral marketing that how their message should be designed so that it can affect the consumer. In addition, findings of this study suggest that it is better that viral advertising message of the companies to be more productive rationally and intellectually for people who have higher involvement level so that consumers believe that the message source is credible. On the other hand, it is recommended that emotional images to be used in the viral message for people who are at the lower involvement level.

The results of this research can be used by all companies employing viral marketing and word of mouth marketing. According to the findings of the research, the following applied recommendations are provided for companies:

1. Research findings show that regardless of people's risk taking level, the source of the message credibility is one of the factors affecting consumer attitude (brand interest, brand honesty, and purchase intention) in the case of brand of the phone manufacturer companies. Therefore, to be successful in viral marketing, these companies should 
design their advertising messages in such a way that consumers feel that the source of $\mathrm{MMCKS}$ the messages is credible.

2. Based on the research literature, when consumers have a high higher level of intellectual involvement to the product, it is better that companies to use intellectual or rational appeals, and when consumers have lower level of intellectual involvement, it is better that emotional appeals including images to be used.

3. When the intellectual involvement of consumers is high, they will pay more attention to source of the message. Therefore, when consumers of the product have higher intellectual involvement, it is better that more attention to be paid on source of message and companies should do their best so that their consumers to perceive that their messages is credible.

Research activities have always been faced with limitation in the implementation that can have an impact on results and reduce its generalization. This study is also no exception. For example, the data collection tool was the questionnaire in this study, and questionnaires have some disadvantages that can affect the results. In addition, in the text of the questionnaire, the name of mobile phone manufacturing companies such as Samsung, LG, Nokia and the iPhone have been mentioned. As a result, users of mobile phones may make mistakes in remembering promoting and advertising activities of the companies, and this can have an impact in the completion of the questionnaire. Additionally, this study was conducted in Bushehr city (Iran). Therefore, we should be cautious in generalizing the findings over the entire population of the country.

\section{References}

Bahrainizadeh, M., and Ziaee, A. (2012), "Investigating the impact of risk aversion and the consumers' involvement with product on their loyalty and their oral advertising: the mediating role of attachment and trust in the brand", New Marketing Research, Vol. 2, No. 4, pp. 105-121. (In Persian)

Beverland, M., Dobelee, A., and Farrelly, F. (2014), "The viral marketing metaphor explored through Vegemite", Marketing Intelligence \& Planning, Vol. 33, No. 5, pp. 656-674.

Cheung, C. M., Lee, M., and Rabjohn, N. (2008), "The impact of electronic word-ofmouth", Internet Research, Vol. 18, No. 3, pp. 229-247.

Chiou, J. and Hsu, A. (2013), "How negative online information affects consumers 'brand evaluation", Online Information Review, Vol. 37 No. 6,pp. 910-926.

Clow, K., James, K., Kranenburg, K., and Berry, C. (2006), "The relationship of the visual element of an advertisement to service quality expectations and source credibility", Journal of Services Marketing, Vol. 20, No. 6, pp. 114-404.

Dinh, T., and Mai, K. (2016), “Guerrilla marketing's effects on Gen Y's word-ofmouthintentiona mediation of credibility", Asia Pacific Journal of Marketing and Logistics, Vol. 28, No. 1, pp. 4-22.

Dobelee, A., Adam, L., Michael, B., Vanhamme, J., and Wijk, R. (2007), "Why pass on viral messages? Because they connect emotionally", Business Horizons, Vol. 50, No. 4, pp. 291-304.

Feiz, D. Fakharyan, M., Jalilvand, M. Hashemi, M. (2013), "Examining the Effect of TV advertising appeals on brand attitudes and advertising efforts in Iran", Journal of Islamic Marketing, Vol. 4, No. 1, pp. 101-125.

Gerard, P., and Liu, P. (2009), "A Hong Kong study of advertising credibility", Journal of Consumer Marketing, Vol. 26, No. 5, pp. 320-329. 
Gunther, A. (1992), "Biased press or biased public: attitudes toward media coverage of social groups”, Public Opinion Quarterly, Vol. 56, No. 2, pp. 67-147.

Hawkins, D., Best, R., and Coney, K. (2003), Consumer Behavior: Building Marketing Strategy, New York: McGraw-Hill.

Jafariani, H., and Doaee, H. (2010), "The impact of viral messages on the message transmit rate in media communication", Communication Research Quarterly, Vol. 7, No. 4, pp. p11-29. (In Persian)

Kachersky, L., Carnevale, M. (2015), "Effects of pronoun brand name perspective and positioning on Brand attitude", Journal of Product \& Brand Management, Vol. 24, No. 2, pp. 10-32.

Kaplan, A., and Haenlein, M. (2011), "Two hearts in three-quarter time: How to waltz the social media/viral marketing dance", Business Horizons, Vol. 14, No. 4, pp. 253-263.

Kim, H .(2005), "Consumer profiles of apparel product involvement and values:", Journal of Fashion Marketing and Management, Vol. 14, No. 4, pp. 207-220.

Kim, H., and Lee, C. (2012), "Differential effects of fear-eliciting DTCA on elaboration, perceived endorser credibility, and attitudes", International Journal of Pharmaceutical and Healthcare Marketing, Vol. 6, No. 1, pp. 22-41.

Lim, B., and Chung, C. (2014), "Word-of-mouth:, Asia Pacific Journal of Marketing and Logistics, Vol. 26, No. 1, pp. 39-53.

Maleki, M., Dehghani, S., Baghani, A., and Farsizadeh, H. (2015), "Examining the impact of service brand dimensions on brand loyalty in the banking industry", New Marketing Research, Vol. 5, No. 4, pp. 119-161. (In Persian)

Moore, R. (2003), "From genericide to viral marketing: on brand", Language \& Communication, Vol. 23, No. 3, pp. 331-357.

Noble, G., and Johnson, L. (2013), "Gender and message appeal: Their influence in a proenvironmental social advertising context”, Journal of social marketing, Vol. 4, No. 1, pp.4-21.

Nowruzi, A., and Qalandari, K. (2009), "Advertising and intellectual involvement of the customer with product", Journal of Tadbir, Vol. 15, No. 11, pp. p 61-64. (In Persian)

O’Reilly, K., and Marx, S. (2011), “How young, technical consumers assess online WOM credibility", Qualitative Market Research: An International Journal, Vol. 14, No. 4, pp. 330-359.

Procter, J., and Richards, M. (2002), "Word-of-mouth marketing: beyond pester power", Young Consumers:Insight and Ideas for Responsible Marketers, Vol. 3, No. 3, pp. 311.

Pongjit, Ch., Beise-Zee, R. (2015), "The effects of word-of-mouth incentivization on consumer brand attitude", Journal of Product \& Brand Management, Vol. 24 ,No 7, pp. 34-50.

Smith, B., McKenzie, J., and Thomas, M. (2005), "Awareness of message source and its association with the impacts of sun protection campaigns in Australia", Health Education, Vol. 105, No. 1, pp. 42-52.

Vazifehdust, A., Kheiri, B., and Ruhani, M. (2010), "Risk aversion and loyalty to a brand", Brand Quarterly, Vol. 1, No. 4, pp. p 26-30. (In Persian)

Wang, C., and Lee, H. (2005), "The effects of source credibility, affection, and involvement in reducing the belief of internet rumors", Journal of Management, Vol. 7, No. 3, pp. 391-413. 
Wu, P., and Wang, Y. (2011), |The influences of electronic word-of-mouth message MMCKS appeal and message source credibility on brand attitude", Asia Pacific Journal of Marketing, Vol. 23 No. 4, pp. 448-472.

Yang, H., Liu, H., and Zhou, L. (2012), "Predicting young Chinese consumers mobile viral attitudes, intents and behavior", Asia Pacific Journal of Marketing and Logistics, Vol. 24, No.1, pp. 59-77. 